\title{
RHINOLOGY
}

\section{Surgical management of inverted papilloma involving the frontal sinus: a practical algorithm for treatment planning}

\author{
Approccio chirurgico al papilloma invertito interessante il seno frontale: \\ un algoritmo pratico per la pianificazione del trattamento
}

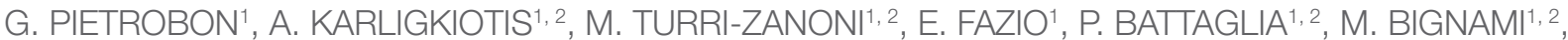 \\ P. CASTELNUOVO1,2 \\ ${ }^{1}$ Division of Otorhinolaryngology, Department of Biotechnology and Life Sciences, University of Insubria, ASST \\ Sette Laghi, Ospedale di Circolo e Fondazione Macchi, Varese, Italy; ${ }^{2}$ Head and Neck Surgery \& Forensic \\ Dissection Research center (HNS\&FDRc), Department of Biotechnology and Life Sciences, University of Insubria, \\ Varese, Italy
}

\begin{abstract}
SUMMARY
Inverted papilloma of the frontal sinus is a challenging disease. Given its rarity, only small case series are present in the literature. The objectives of the present study are to review our experience in the surgical management of inverted papillomas involving the frontal sinus and to propose a practical algorithm for selecting the most appropriate approach. Data on patients affected by inverted papilloma involving the frontal sinus and surgically treated between 2002 and 2016 were collected. The type of involvement of frontal sinus and extent of surgery performed (endoscopic endonasal, external or combined approaches) were analysed. A brief review of consistent literature was also carried out. Forty-seven consecutive patients were treated using an exclusive endoscopic endonasal approach (EEA) in 18 cases, while a combined endonasal with external osteoplastic approach was required in 29 cases. Most patients $(29 / 47,62 \%)$ had been treated previously, mainly by an endoscopic approach. A single intraoperative complication occurred (1/47, 2\%), i.e. cerebrospinal fluid (CSF) leak, that was successfully repaired intraoperatively without any consequences. Recurrences were observed in only $2 / 47$ cases (4\%) after a mean follow-up of 43 months (range, 12-137). The management of inverted papilloma involving the frontal sinus requires great expertise and the surgical technique should be tailored to the site of attachment of the tumour, its extension and the anatomical conformation of each frontal sinus. The encouraging results obtained in this case series support the use of this practical treatment algorithm.
\end{abstract}

KEY WORDS: Inverted papilloma • Frontal sinus • Endoscopic sinus surgery • Osteoplastic flap • Orbital transposition

\section{RIASSUNTO}

Il papilloma invertito del seno frontale è una patologia di non facile gestione. Data la sua rarità, in letteratura si possono ritrovare solo casistiche di dimensioni ridotte. Gli obiettivi del presente studio sono, da un lato, il presentare la nostra esperienza nella gestione chirurgica del papilloma invertito interessante il seno frontale e, dall'altro, il proporre un algoritmo pratico per la selezione del miglior approccio. Sono stati raccolti i dati dei pazienti affetti da papilloma invertito del seno frontale e trattati chirurgicamente dal 2002 al 2016. Sono stati analizzati il tipo di coinvolgimento del seno frontale e l'invasività della procedura chirurgica (endoscopica endonasale, esterna o combinata). È stata, inoltre, condotta una breve revisione della letteratura al riguardo. Complessivamente la casistica è risultata composta da 47 pazienti, di cui 18 trattati con approccio puramente endoscopico endonasale, mentre i restanti 29 con approccio combinato endoscopico con lembo osteoplastico frontale. La maggior parte dei pazienti era stata trattata precedentemente presso altri centri (29/47, 62\%), prevalentemente tramite un approccio endoscopico endonasale. È stata riscontrata una singola complicanza intraoperatoria (1/47, 2\%), rappresentata da una fistola rinoliquorale, immediatamente riparata e scevra di successive sequele. Sono state individuate due recidive di malattia (2/47, 4\%) dopo un follow up medio di 43 mesi (range 12-137). La gestione del papilloma invertito interessante il seno frontale richiede una valida esperienza e la tecnica chirurgica deve essere adeguata al sito d'attacco del tumore, alla sua estensione e alla conformazione dei seni frontali. I risultati incoraggianti ottenuti nella nostra casistica supportano l'utilizzo di questo algoritmo pratico di trattamento.

PAROLE CHIAVE: Papilloma invertito $\bullet$ Seno frontale $\bullet$ Chirurgia endoscopica nasosinusale $\bullet$ Lembo osteoplastico frontale $\bullet$ Trasposizione orbitaria 


\section{Introduction}

Inverted papilloma is the most common epithelial benign tumour of the nose and paranasal sinuses, accounting for approximately 0.5 to $4 \%$ of all sinonasal neoplasms ${ }^{1}$. It arises from the Schneiderian mucosa and grows into the underlining stroma with a typical endophytic pattern. Though considered a benign lesion, this tumour is characterised by a well-known tendency to relapse in case of incomplete removal ${ }^{2}$ and by a variable association with squamous cell carcinoma, either synchronous or metachronous ${ }^{134}$. These features, along with frequently associated bony alterations (erosion or osteosis), make inverted papilloma an unpleasant lesion, which needs to be approached carefully and excised thoroughly.

The frontal sinus is an anatomically challenging region, both functionally and aesthetically: its anterior wall gives shape to the forehead, while its posterior wall encloses the frontal lobes, i.e. the ventral edge of the anterior cranial fossa. Inverted papilloma involving the frontal sinus represents only $2.5 \%$ of all cases ${ }^{5}$ and has been traditionally managed through external transcranial approaches ${ }^{3}$. Nowadays, the endoscopic endonasal technique is considered the gold standard approach for the treatment of sinonasal Schneiderian papillomas ${ }^{6}$, without the common post-surgical complications of the external approaches, let alone reduced discomfort for patients and time of hospitalisation ${ }^{7}$. However, endoscopic access to the frontal sinus can still be challenging because of its anatomy and unfavourable position, requiring curved instrumentation and the necessity to control any of its recesses when dealing with either benign or malignant tumours.

To date, there is still debate about the best technique to address inverted papillomas in this site and no definitive guidelines exist. The aims of this study are to share our experience in the management of inverted papilloma arising from or extending into the frontal sinus, and to propose a practical algorithm for the surgical management of these lesions. The different surgical procedures available and their specific indications are also discussed and reviewed along with the small amount of data present in the literature.

\section{Materials and methods}

\section{Study design}

A retrospective review of a single institutional database on inverted papillomas arising from or extending to the frontal sinus, treated surgically between July 2002 and December 2016, was performed. Approval was obtained from the Insubria Board of Ethics. The following data were collected: sex, age at intervention, side involved, symptoms at presen- tation, previous treatments, origin and extension of disease, type of surgery, early and late complications, histology, time of follow-up and recurrence. Inclusion in the study required a minimum follow-up of 12 months.

\section{Pre-operative work-up}

A plain CT scan and/or a contrast-enhanced MRI were obtained in all cases. All patients were also submitted to endoscopic endonasal evaluation to identify intranasal extension of the lesion. A biopsy under local anaesthesia was always performed after imaging evaluation to confirm diagnosis and assess for possible coexistence of carcinomatous foci.

\section{Surgical strategies}

All surgical procedures were performed under general anaesthesia. The entity of dissection was modulated in relation to the site and extent of the lesion defined by preoperative imaging and intraoperative findings. Informed consent about the possibility of intraoperatively switching from an endoscopic to a combined endoscopic-transcranial approach was obtained in all patients, especially for those with massive frontal sinus and/or supraorbital cell involvement. When present, the naso-ethmoidal and maxillary sinus component of the inverted papillomas were treated according to the three different types of endoscopic procedures (Types 1, 2, 3), which have been extensively described in a previous publication (Table I) ${ }^{8}$. An endoscopic frontal sinusotomy (type I, IIA, IIB, or III) according to Draf ${ }^{9}$ was performed in all cases.

Whenever a mucosal involvement inside a supraorbital

Table I. Summary of surgical steps in the 3 types of endoscopic procedures ${ }^{8}$.

\begin{tabular}{|c|c|}
\hline $\begin{array}{l}\text { Type of endoscopic } \\
\text { procedure }\end{array}$ & Surgical steps \\
\hline 1 & $\begin{array}{l}\text { Anterior and posterior ethmoidectomy, } \\
\text { sphenoidotomy, large middle antrostomy, partial } \\
\text { or complete middle turbinectomy, } \\
\text { frontal sinusotomy } \\
\text { (type I, IA, IIB, or III according to Draf's classification }{ }^{9} \\
\text { in relation to the extent of disease) }\end{array}$ \\
\hline 2 & $\begin{array}{l}\text { Anterior and posterior ethmoidectomy, } \\
\text { sphenoidotomy, medial maxillectomy, partial or } \\
\text { complete middle turbinectomy, frontal sinusotomy } \\
\text { (type I, IIA, IIB, or III according to Draf's classification }{ }^{9} \\
\text { in relation to the extent of the disease) } \\
\text { ( } \pm \text { naso-lacrimal duct section) }\end{array}$ \\
\hline 3 & $\begin{array}{l}\text { Anterior and posterior ethmoidectomy, } \\
\text { sphenoidotomy, endonasal Denker operation with } \\
\text { naso-lacrimal duct section, complete inferior and } \\
\text { middle turbinectomy, frontal sinusotomy } \\
\text { (type I, IIA, IIB, or III according to Draf's classification }{ }^{9} \\
\text { in relation to the extent of disease) }\end{array}$ \\
\hline
\end{tabular}




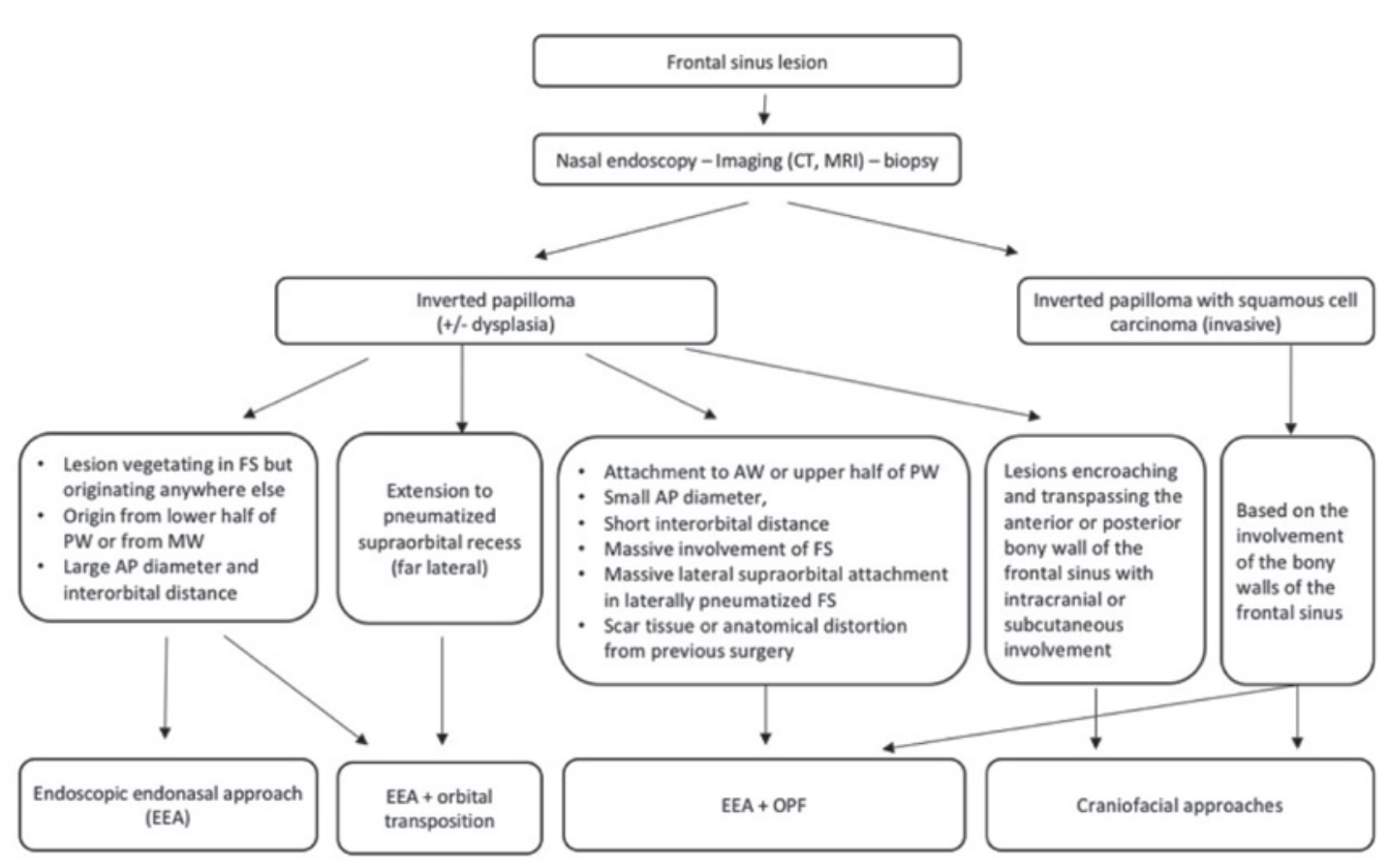

Fig. 1. Practical algorithm used to plan surgical resection of frontal sinus inverted papilloma. AP: anteroposterior; FS: frontal sinus; PW: posterior wall; MW: medial wall; AW: anterior wall; OPF: osteoplastic flap; EEA: endoscopic endonasal approach.

cell extending far laterally over the orbital roof was identified, resection was performed, or anyway attempted as first step, using an endoscopic endonasal orbital transposition approach ${ }^{10}$, which has become common practice in the last decade. In case of massive involvement of the frontal sinus, particularly when highly pneumatised, an osteoplastic flap (OPF) using a bicoronal approach was planned. Inverted papillomas encroaching and possibly crossing the anterior or posterior bony wall of the frontal sinus, with intracranial extension or subcutaneous involvement, or inverted papillomas associated with squamous cell carcinoma, should be treated using traditional transcranial approaches (Riedel's technique and its modifications or classic craniofacial resection) ${ }^{11}{ }^{12}$. The practical algorithm used to plan the surgical resection is summarised in Figure 1. Frozen sections were extensively used intraoperatively to ensure a free-margins resection. Based on the radiological and surgical findings, all tumours were staged according to the system of Krouse ${ }^{13}$.

\section{Follow-up}

Patients were followed after surgery with serial endoscopic endonasal evaluations. Irrigations with saline solution (twice daily) were recommended for at least 1 month. Post-operative contrast-enhanced MRI scans were performed at 6 months after surgery and thereafter in the presence of scar tissue obscuring the visualisation of the site of origin of the lesion (every 6 months for the first 2 years and then once a year for the following 3 years). Postoperative MRI evaluation was scheduled in case of clinical or endoscopic suspect of local recurrence.

\section{Results}

\section{Patient population}

Forty-seven patients fulfilled the inclusion criteria and were included in the study. There were 34 males and 13 females $(\mathrm{M}: \mathrm{F}=2.5: 1)$. Age at surgery ranged from 26 to 78 years (mean 57 years). Frontal sinus was the site of origin of the tumour in 16 cases; the remaining patients had the frontal sinus involved as extension from the anterior ethmoid (27 cases, including frontal recess in 2 cases) and posterior ethmoid (4 cases). Bilateral involvement of the frontal sinus was present in 9 patients (20\%), in 5 of whom the tumour originated from the frontal sinus. Nasal obstruction was the most common symptom (32 patients, $67 \%$ ), followed by headache, either as the main $(7 \%)$ or associated complaint (31\%). Nasal discharge was present in only 6 patients (14\%) and anosmia in 3 $(7 \%)$. Four patients $(8 \%)$ were asymptomatic and diagnosed incidentally during head imaging for other causes.

Before treatment in our tertiary care referral centre, 30 
patients had been already treated surgically elsewhere, almost all with an exclusive endoscopic approach (29 cases) except for one case treated with an external Caldwell-Luc procedure. Prior to surgery, the available imaging was a combination of CT scan and contrast-enhanced MRI in 38 cases $(80 \%)$, CT scan alone in 5 cases $(10 \%)$ and only MRI in 4 cases (9\%). All clinical and demographic data are summarised in Table II.

\section{Surgical procedure}

Patients were divided in two groups: one group included all patients treated with an exclusive endoscopic endonasal approach, while the other one included all patients treated with a combined endoscopic-OPF approach. No case in the present series fulfilled the requirements for a classic or

Table II. Clinical and demographic data of patients.

\begin{tabular}{|c|c|c|}
\hline Number of patients & \multicolumn{2}{|c|}{47} \\
\hline $\begin{array}{l}\text { Sex } \\
\text { Male } \\
\text { Female }\end{array}$ & $\begin{array}{l}34 \\
13\end{array}$ & $\begin{array}{l}72 \% \\
28 \%\end{array}$ \\
\hline Mean age (range) & \multicolumn{2}{|c|}{57 years (26-78) } \\
\hline $\begin{array}{l}\text { Side of lesion } \\
\text { Right } \\
\text { Left } \\
\text { Bilateral }\end{array}$ & $\begin{array}{c}21 \\
17 \\
9\end{array}$ & $\begin{array}{l}45 \% \\
36 \% \\
19 \%\end{array}$ \\
\hline $\begin{array}{l}\text { Site of origin } \\
\text { Frontal sinus } \\
\text { Ethmoid }\end{array}$ & $\begin{array}{l}16 \\
31\end{array}$ & $\begin{array}{l}34 \% \\
66 \%\end{array}$ \\
\hline $\begin{array}{l}\text { Previous surgery } \\
\text { None } \\
\text { Endoscopic } \\
\text { External }\end{array}$ & $\begin{array}{c}17 \\
29 \\
1\end{array}$ & $\begin{array}{c}36 \% \\
62 \% \\
2 \%\end{array}$ \\
\hline $\begin{array}{l}\text { Imaging } \\
\text { CT } \\
\text { MRI } \\
\text { CT+MRI }\end{array}$ & $\begin{array}{c}5 \\
4 \\
38\end{array}$ & $\begin{array}{c}10 \% \\
9 \% \\
81 \%\end{array}$ \\
\hline $\begin{array}{c}\text { Type of surgery } \\
\text { EEA (with OT) } \\
\text { EEA + OPF }\end{array}$ & $\begin{array}{c}18(8) \\
29\end{array}$ & $\begin{array}{c}38 \%(17 \%) \\
62 \%\end{array}$ \\
\hline $\begin{array}{l}\text { Histology } \\
\text { Inverted papilloma } \\
\text { Oncocytic papilloma }\end{array}$ & $\begin{array}{c}46 \\
1\end{array}$ & $\begin{array}{l}98 \% \\
2 \%\end{array}$ \\
\hline $\begin{array}{l}\text { Associated histology } \\
\text { None } \\
\text { Mild dysplasia } \\
\text { Moderate dysplasia } \\
\text { Severe dysplasia } \\
\text { Carcinoma in situ } \\
\text { SCC }\end{array}$ & $\begin{array}{c}37 \\
3 \\
5 \\
1 \\
- \\
1\end{array}$ & $\begin{array}{c}79 \% \\
6 \% \\
11 \% \\
2 \% \\
- \\
2 \%\end{array}$ \\
\hline $\begin{array}{l}\text { Recurrences } \\
\text { No } \\
\text { Yes }\end{array}$ & $\begin{array}{c}45 \\
2\end{array}$ & $\begin{array}{c}96 \% \\
4 \%\end{array}$ \\
\hline Mean follow-up (range) & & -137) \\
\hline
\end{tabular}

OT: orbital transposition; OPF: osteoplastic flap modified Riedel's procedure or for a classic craniofacial resection, hence these approaches were never performed. A purely endoscopic endonasal approach (EEA) was used in 18 patients (38\%): Type 1 resection was performed in 11 cases, Type 2 in 2 cases and Type 3 in 5 cases. In this group of patients, the frontal sinus was the site of origin of the disease in 3 cases $(3 / 18,17 \%)$. In 8 cases an endoscopic orbital transposition was performed in order to resect a lesion located in the supraorbital recess (Fig. 2). The frontal sinusotomy was a Draf type 1 in 2 cases $(2 / 18$, $11 \%)$, a Draf type $2 \mathrm{a}$ in 3 cases $(3 / 18,17 \%)$, a Draf type $2 \mathrm{~b}$ in 11 cases $(11 / 18,61 \%)$ and a Draf type 3 in 2 cases $(2 / 18,11 \%)$. Figure 3 shows pre-operative extension and post-operative results of a patient successfully treated with an EEA. No case required conversion from a purely endoscopic endonasal procedure to an OPF.

Conversely, a combined EEA with OPF was necessary in 29 patients $(62 \%)$, of whom 11 had the frontal sinus as a primary site of origin of the tumour $(13 / 29,45 \%)$ (Fig. 4). A Draf type $2 \mathrm{~b}$ frontal sinusotomy was performed in 12 cases $(12 / 29,41 \%)$, while a Draf type 3 was performed in the remaining cases $(17 / 18,59 \%)$. Figure 5 shows preoperative extension and post-operative results of a patient treated with combined EEA-OPF resection.

To note, choice of the most appropriate approach was driven not only by the origin site, but also by intraoperative evidence of diseased mucosa in the frontal sinus. Table III illustrates the different approached used, based on the sites encroached by the lesion. A combined EEA with OPF was more often required if the lesion involved either the anterior or posterior walls of the sinus or the supraorbital recess or multiple sites.

\section{Histology and classification}

Final histology was consistent with inverted papilloma in 46 cases, while in one case it required a combined EEA with OPF in whom an oncocytic papilloma was diagnosed. Variable levels of dysplasia were observed within the surgical specimens: mild dysplasia in 3 cases, moderate in 5 cases and severe in 1 case.

In one patient, a 64-year-old female, a synchronous invasive squamous cell carcinoma was identified. The inverted papilloma originated in the left frontal sinus and extended in the ethmoidal compartment and nasal fossa. A combined EEA with OPF approach was used. Final histology showed focal invasive squamous cell carcinoma, moderately differentiated, involving the vegetating nasal portion of the lesion, without infiltration of the ethmoidal and frontal components. This case was discussed post-operatively during a multidisciplinary meeting and neither revision surgery nor adjuvant radiation therapy was deemed necessary. 


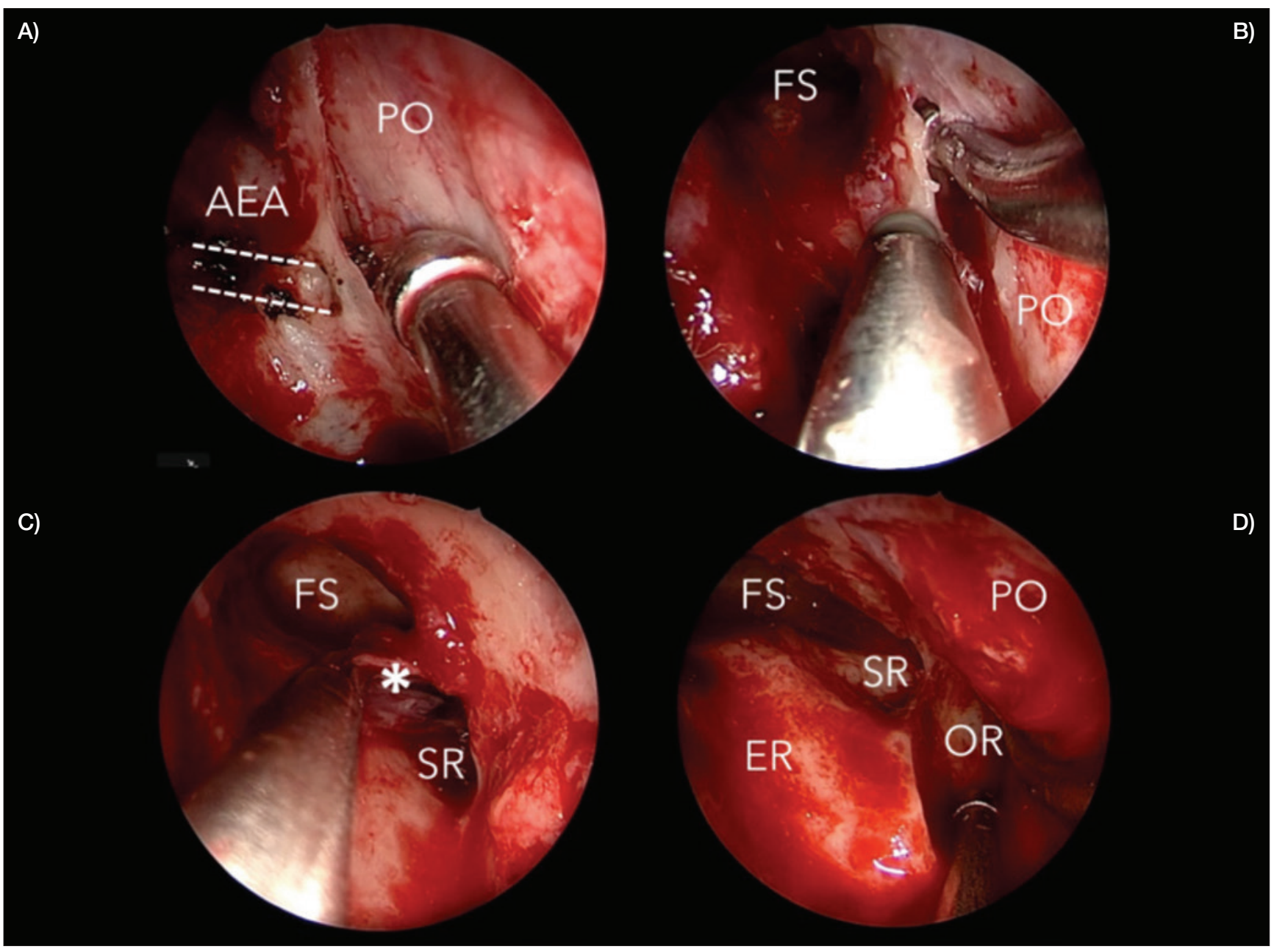

Fig. 2. Endonasal endoscopic orbital transposition to resect inverted papilloma involving the supraorbital recess. Once the periorbit has been exposed and the AEA cauterised and cut (A), access to the supraorbital recess is gained by drilling the supero-medial orbital wall (B), while the periorbit is pushed laterally to be protected and to expose completely the orbital roof; following removal of the most lateral portion of the lesion (C), inspection of both the recess and the orbital roof is possible (D). AEA: anterior ethmoidal artery; PO: periorbit; FS: frontal sinus; SR: supraorbital recess; ER: ethmoidal roof; OR: orbital roof; white asterisk marks the tumour.

According to Krouse staging of disease ${ }^{13}$, involvement of the frontal sinus defines tumour as T3, and thus this was the final stage for all patients except for the one with associated synchronous carcinoma, defined as T4.

\section{Complications and follow-up}

In a single occasion, during a purely endoscopic endonasal approach, an intraoperative CSF leak occurred at the level of the left olfactory fissure, and thus a skull base reconstruction with a free graft of nasal mucoperiosteum placed overlay was performed. Neither recurrent leakage nor further complications were observed.

During follow-up (mean, 43 months; median, 32 months; range, 12-137 months), 17 patients (35\%) presented with frontal stenosis, most of the time symptomless $(12 / 17,71 \%)$,
2 other patients (4\%) with mucoceles and 1 additional patient (2\%) with epiphora (Table IV). Of 17 cases with frontal stenosis, the frontal sinusotomy performed during resection of the IP was a Draf type 1 and a Draf type 2a in 1 case each, a Draf type $2 b$ in 7 cases and a Draf type 3 in 8 cases. Both cases with mucoceles and 5 cases of frontal stenosis required revision surgery using an endoscopic endonasal approach. The patient complaining of epiphora was successfully treated with endoscopic dacriocystorhinostomy.

During follow-up, two patients (4\%) experienced recurrence of disease and were consequently re-operated at, respectively, 8 and 40 months after the first surgical procedure. The first presented with inverted papilloma originating in the right posterior ethmoid and extending into the frontal sinus and was submitted to an EEA. He 

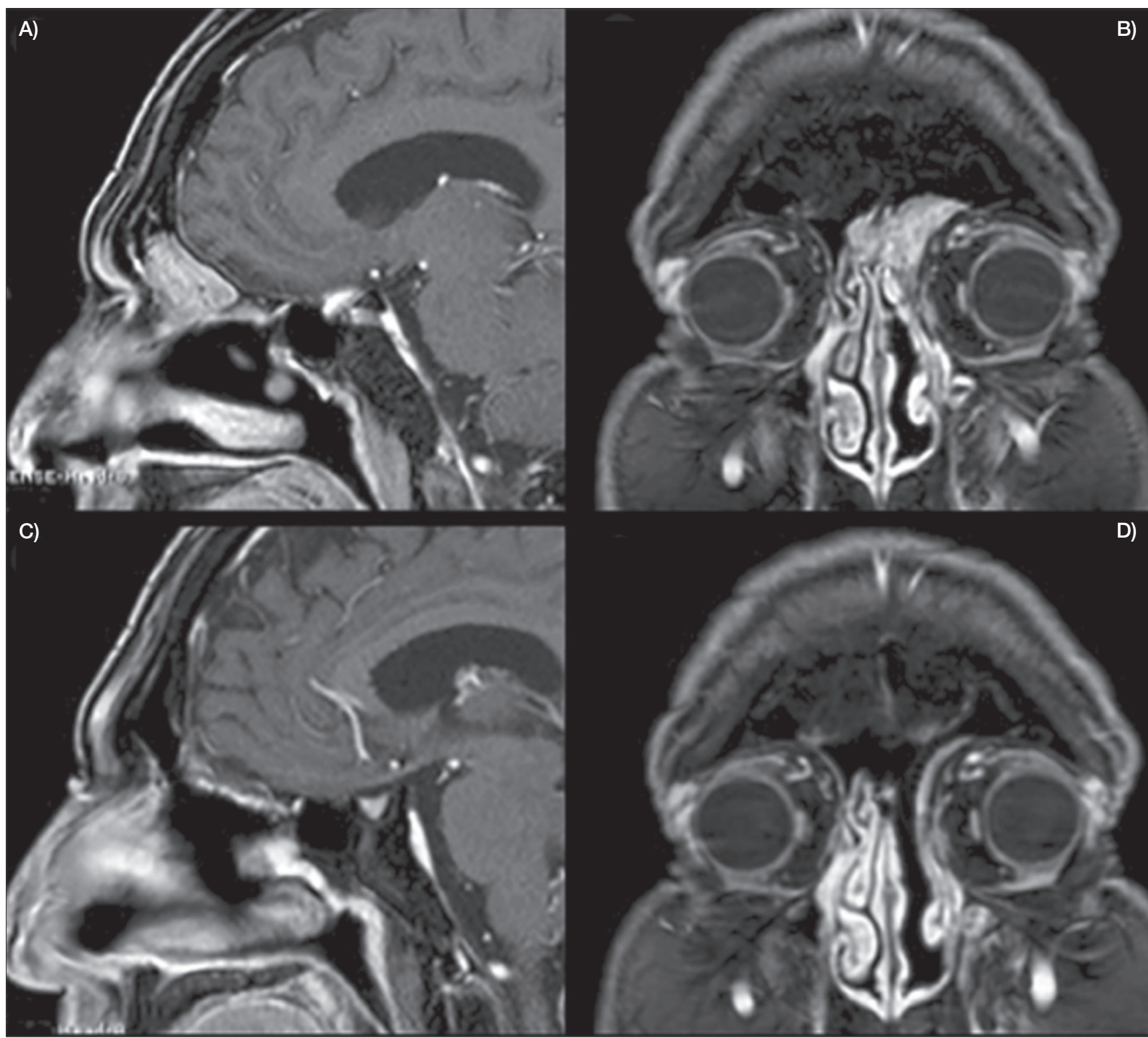

Fig. 3. T1-weighted MRI with gadolinium. Pre-operative (A, B) and post-operative (C, D) imaging of left fronto-ethmoidal inverted papilloma in sagittal and coronal views. Post-operative evidence of patent frontal drainage pathway and absence of disease is shown.

later developed a recurrence in the frontal sinus, which required a combined EEA with OPF. The second patient initially presented with inverted papilloma arising from the anterior wall of the right frontal sinus and extending into the ipsilateral ethmoidal compartment and maxillary sinus, and she was submitted to a combined EEA with OPF. She later developed frontal stenosis and complained of unbearable frontal headache, so she underwent revision surgery through a combined EEA with OPF: intraoperatively, suspicious tissue was removed from inside the frontal sinus and was compatible with IP at final histol- ogy. After 44 and 100 months of follow-up, respectively, these patients are alive without evidence of disease.

To note, the patient with diagnosis of synchronous squamous cell carcinoma was followed with stricter clinical endoscopic and radiological exams with contrast-enhanced MRI evaluations every 6 months and a total body CT scan once per year. She is currently alive without recurrence of disease after 96 months of follow-up.

\section{Discussion}

As already pointed out throughout the literature ${ }^{28}$, resec- 


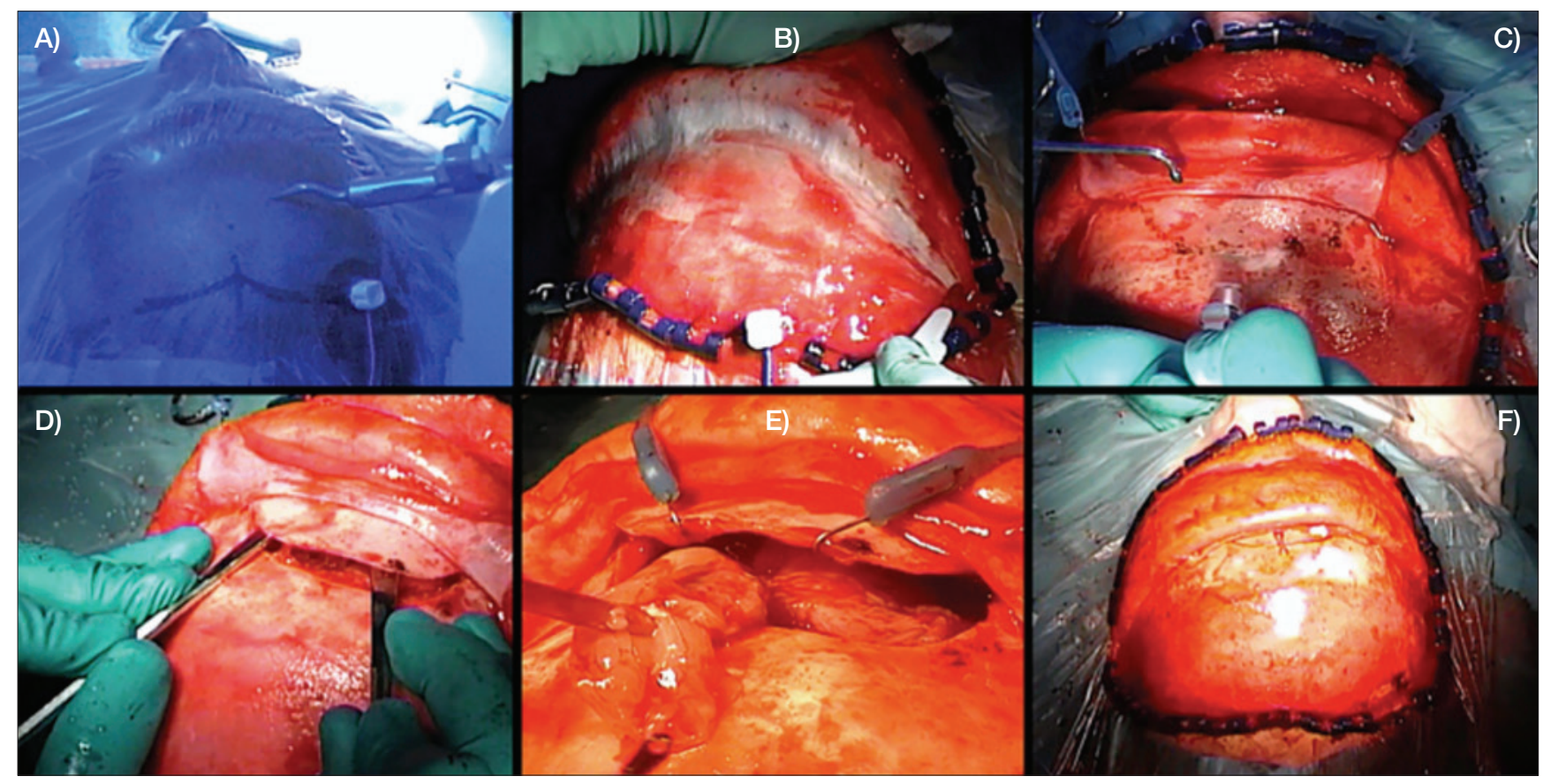

Fig. 4. Intraoperative views of an osteoplastic flap (OPF). After placement of a cranial pin and set up for magnetic navigation (A), a cutaneous-galeal flap is raised (B), followed by harvesting of a pericranial flap, which is held by small hooks (C). Osteotomies are realised with an oscillating saw (C) and chisels (D) in order to create an inferiorly-pedicled osteoplastic flap and to gain access to the lesion inside the frontal sinus (E). At the end of the procedure the osteoplastic flap is flipped back in place and screwed (F).

tion of inverted papilloma should be particularly focused on the attachment site of the lesion: removal of the mucosa together with the periosteal layer followed by the drilling of the underling bone is crucial to avoid recurrences. This is the reason why the pre-operative identification of the tumour's site of attachment on radiological imaging is paramount. Endoscopic endonasal eradication is relatively accessible whenever the tumour involves the maxillary, ethmoid or sphenoidal sinuses; conversely, it can become difficult if the frontal sinus mucosa is interested by the tumour and the lesion does not simply vegetate inside the sinus. This is particularly true in case of extensive involvement of the sinus, which may preclude complete visualisation of the lesion and reduce the manoeuvrability of instruments.

Recently, a novel technique has been described to expand the EEA to lesions occupying the far lateral recess/ supraorbital recess of the frontal sinus, the so-called endoscopic orbital transposition. This technique, based on a superomedial orbital wall decompression with preservation of the periorbital integrity, allows lateral dislocation of the orbital content, making the surgeon able to reach further in the lateral recess, thanks to a combined Draf type IIb or Draf type III frontal sinusotomy. As a consequence, inverted papilloma arising in the frontal sinus, laterally to a sagittal plane passing through the lamina papyracea, may no longer be considered as an absolute contraindication to EEA.

However, when the site of attachment is located on the superior, lateral, or anterior wall of the frontal sinus as well as in case of massive involvement of the frontal sinus mucosa or in case of a highly-pneumatised frontal sinus, endoscopic endonasal resection is highly challenging, as already stated by other authors ${ }^{14}{ }^{15}$. In such cases, extended endoscopic approaches allow debulking of the tumour and identification of the sites of tumour attachment, but they may be not sufficient to eradicate the lesion; hence, open approaches are usually necessary, namely an osteoplastic flap (OPF) or an endoscopic frontal trephination (EFT). Of note, despite being mandatory to obtain preoperative plain CT scan and gadolinium-enhanced MRI to evaluate the origin and extension of the lesion and to plan the most suitable surgical approach, the final tumour encroachment can be clearly assessed only intraoperatively, aided by frozen sections, so that any possible site of attachment may be eradicated.

Recently, a new technique based on a combined endoscopic endonasal and transpalpebral orbitofrontal minicraniotomy has been proposed by Albathi et al. ${ }^{16}$. Though innovative, this experience is very limited, with only 4 cases described, and thus it is definitely too early to draw any conclusions about its efficacy and long-term outcomes. 

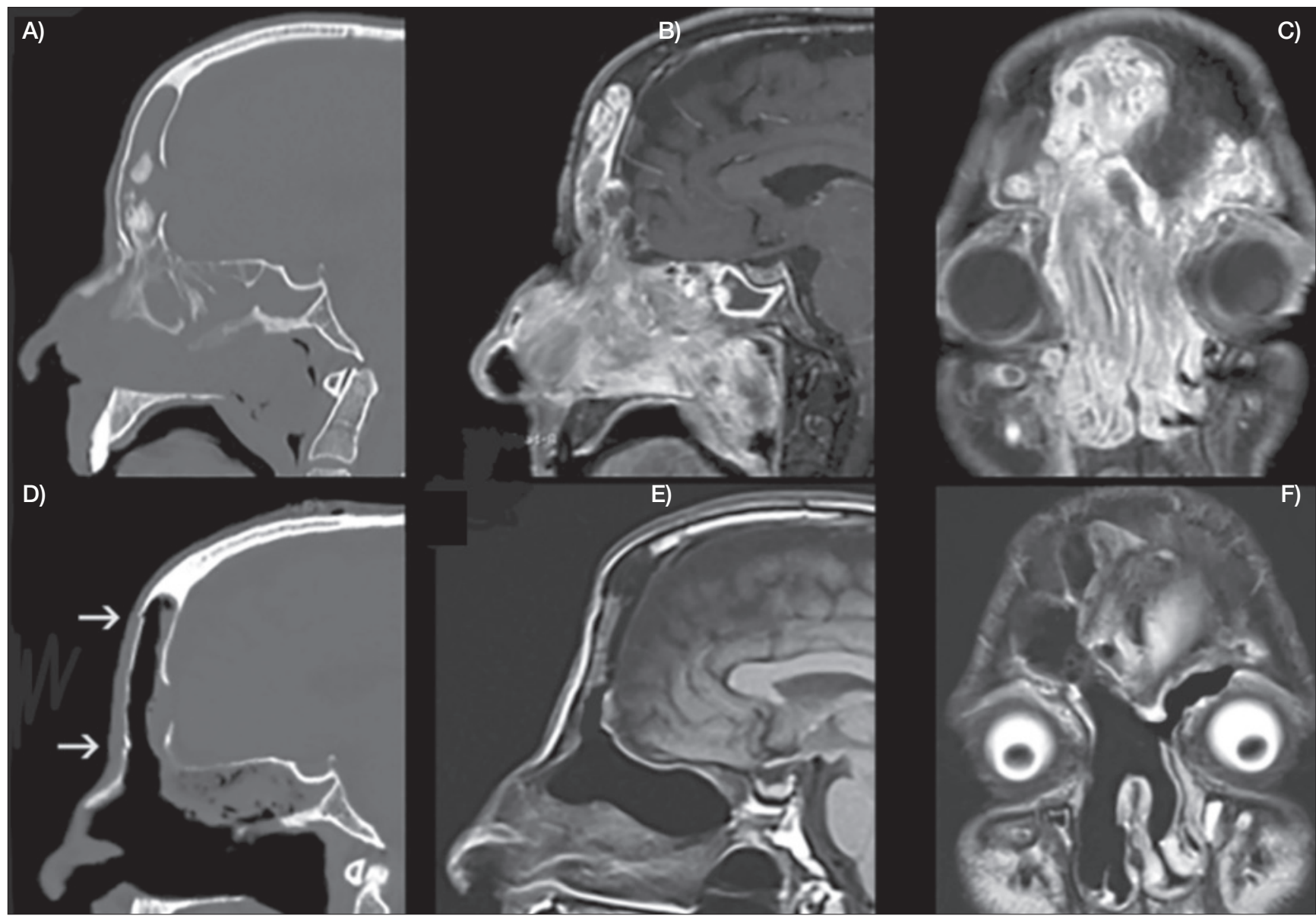

E)

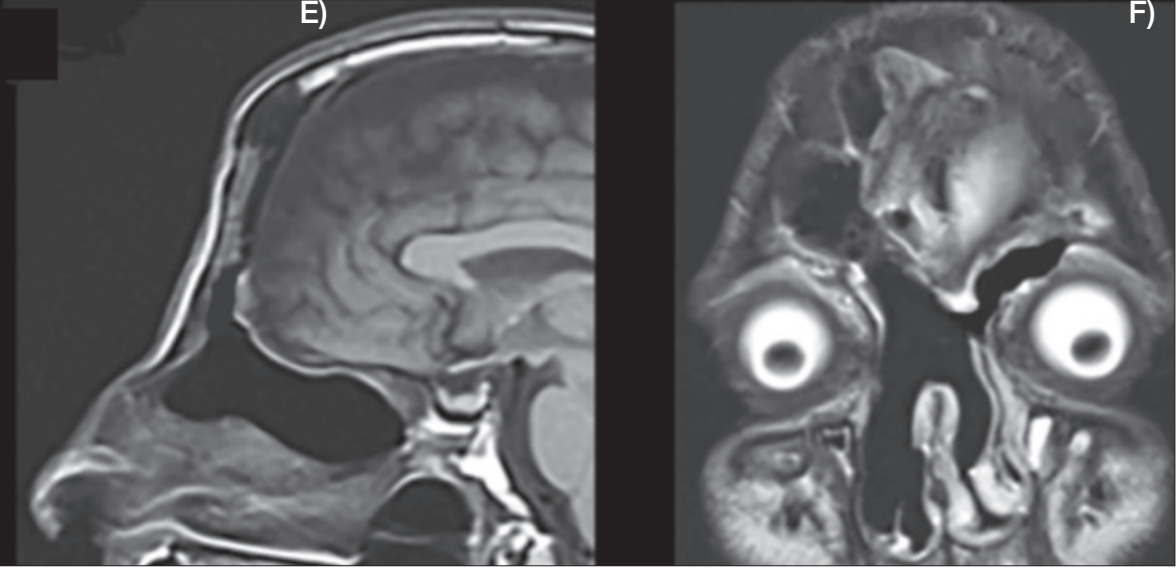

Fig. 5. Pre-operative imaging and post-operative outcomes of a massive inverted papilloma involving the frontal sinuses bilaterally with posterior wall bony erosion, successfully treated by combined endonasal with OPF approach. White arrows point out the osteotomies on the anterior frontal plate.

At present, in cases unfit for endonasal endoscopic eradication, we prefer to use the OPF because it offers better aesthetic results, allows complete access to the frontal sinus and is safer, since it can be performed using ENT magnetic navigation systems, as previously described ${ }^{17}$. At the end of this procedure, the bone flap is replaced and fixed with screws, without obliteration of the sinus. Whenever an OPF was required, this was carried out as a single stage operation, combining it with endoscopic endonasal surgery to simultaneously rehabilitate natural frontal sinus drainage. There is no need, in our opinion, to stage a second surgery as suggested by other studies ${ }^{14}$. Moreover, no major intraoperative or postoperative complications occurred in our series: this is consistent with the learning curve and acquired experience of the surgeons as well as the evolution of the technique since the first review was published ${ }^{18}$. Other authors reserve OPF for extreme cases and propose to use EFT, which is exploited to introduce instruments or endoscope ${ }^{15}$. However, in that paper, the non-negligible recurrence rate (22\%) and associated complications [CSF leak in
1 of 5 cases (20\%) with EFT] ${ }^{15}$ suggest a limited use for this technique, and only in very well selected cases.

Inverted papilloma with intracranial extension is a rare finding with only 17 cases described in English literature and is usually seen in recurrent cases ${ }^{11}{ }^{12}$. Anterior cranial fossa invasion occurs after destruction of the posterior table of frontal sinus or the roof of the nasal cavity. Data from the literature suggest that this uncommon condition can be effectively managed by craniofacial resection $(\mathrm{CFR})^{11}{ }^{12}$. Although no cases in our series required such an aggressive approach, this surgical option has been included within the rationale for management of these challenging tumours (Fig. 1).

Several case series analysing surgical management of frontal sinus inverted papilloma have been published recently ${ }^{19-23}$, although numbers are obviously poor because of the rarity of the disease and the uncommon location. Table $\mathrm{V}$ provides a brief review of the English literature on articles concerning treatment of inverted papilloma of the frontal sinus from 2002 onwards. 
Table III. Sites of attachment of IP inside the frontal sinus and surgical technique adopted.

\begin{tabular}{lcccc}
$\begin{array}{l}\text { Sites } \\
\text { of attachment }\end{array}$ & EEA & EEA + OT & EEA + OPF & Total \\
PW & 3 & - & 7 & 10 \\
AW & 1 & - & 4 & 5 \\
MW & - & - & 1 & 1 \\
LW & - & - & 1 & 1 \\
SR & - & 8 & 10 & 18 \\
FR & 5 & - & 2 & 7 \\
PW+FR & 1 & - & 1 & 2 \\
PW+SR & - & - & 1 & 1 \\
PW+LW & - & - & 1 & 1 \\
AW+SR & - & - & 1 & 1 \\
Total & 10 & 8 & 29 & 47 \\
\hline
\end{tabular}

EEA: endoscopic endonasal approach; OPF: osteoplastic flap; PW: posterior wall; $A W$ : anterior wall; MW: medial wall; LW: lateral wall; SR: supraorbital recess; FR: frontal recess.

Recently, Walgama et al published a review of the literature that was unable to demonstrate the superiority of one surgical approach over the others for successful removal of inverted papilloma of the frontal sinus ${ }^{24}$. The authors concluded that surgeons should be able to handle all different types of techniques and to be ready to convert from endoscopic to external approaches whenever dictated by intraoperative findings, possibly with a single-stage operation. The same review showed an overall recurrence rate of $22.4 \%$ which was lower in case of origin of the lesion from the posterior wall and in case of secondary disease, though without any statistical significance $(\mathrm{p}=0.051$ and $p=0.074$, respectively). Posterior-wall lesions are probably the most accessible ones, and thus radical resection is achieved more often. As far as secondary lesions are concerned, this trend can be probably explained by a more aggressive approach adopted due to the natural history of the disease. We are not able to infer any data from our recurrent cases $(2 / 47,4 \%)$ because of insufficient statis-

Table IV. Early and late post-operative complications according to surgical technique.

$\begin{array}{ccc} & \text { Early complications } & \text { Late complications } \\ \text { EEA (18) } & 1 \text { CSF leakage } & 6 \text { frontal stenosis } \\ & (1 / 18,6 \%) & (6 / 18,33 \%) \\ & 1 \text { epiphora } \\ & (1 / 18,6 \%) \\ \text { EEA + OPF (29) } & - & 11 \text { frontal stenosis } \\ & (11 / 29,38 \%) \\ & 2 \text { mucoceles } \\ & (2 / 29,7 \%)\end{array}$

Total (47)

1

$(1 / 47,2 \%)$

20

(20/47, 43\%) tical power and completely different features of the patients (combined approach for an IP originating from the frontal sinus; EEA for an IP originating from the anterior ethmoid). Of note, both patients presented with persistent/ recurrent IP after being submitted to an endoscopic endonasal procedure at another centre, thus underlying the role of residual scar tissue and distorted anatomy in hindering the revision surgery, as already stated by other authors ${ }^{20}$.

Globally, the recurrence rate of $4 \%$ reported in our study is similar to what is described in more recent studies ${ }^{20}$. When considering only papillomas originating from the FS, the recurrence rate is $1 / 16(6 \%)$, which is definitely lower than the above-cited review ${ }^{24}$ or more recent papers ${ }^{25}$. We believe that these data strongly support the efficacy and safety of the surgical algorithm herein proposed for the management of inverted papilloma involving the frontal sinus. As a general rule, we prefer an exclusively endoscopic endonasal approach whenever feasible, in order to decrease morbidity for patients and reduce hospitalisation time ${ }^{26}$. However, it is our opinion that some cases pose an absolute contraindication to pure EEA, which would result in incomplete resection of disease. Current contraindications for an EEA in the surgical management of frontal sinus inverted papilloma ${ }^{10}$ are summarised as follows:

- small antero-posterior diameter of the frontal sinus $(<1 \mathrm{~cm})$ and small interorbital distance;

- erosion of the posterior wall of the frontal sinus with intracranial extension;

- extension of the lesion through the anterior frontal plate;

- massive lateral supraorbital attachment of the lesion in laterally-pneumatised frontal sinus;

- attachment of the tumour to the anterior wall or to the upper half of the posterior wall of the frontal sinus;

- massive involvement of the mucosa of the frontal sinus and/or of supraorbital cell;

- histological evidence of SCC in IP at pre-operative biopsies or intraoperatively with frozen sections;

- presence of abundant scar tissue from previous surgery or relevant post-traumatic anatomic changes of the frontal bone.

\section{Conclusions}

To the best of our knowledge, this is the largest single-centre case series of inverted papilloma involving the frontal sinus, either as origin or extension. The practical algorithm for surgical treatment planning of such lesions is based on the site of attachment of the lesion and the anatomical conformation of the frontal sinus, and is supported by a very low recurrence rate (4\%) and minimal complications observed. 
Table V. Review of English literature on surgical treatment of frontal sinus inverted papilloma (2002-2017).

\begin{tabular}{|c|c|c|c|c|c|c|c|c|c|}
\hline Author & Year & $\begin{array}{l}\text { Total } \\
\text { cases }\end{array}$ & $\begin{array}{l}\text { Cases with FS } \\
\text { involvement }\end{array}$ & $\begin{array}{c}\text { Type } \\
\text { of surgery }\end{array}$ & Results & $\begin{array}{c}\text { No. } \\
\text { of relapses }\end{array}$ & $\begin{array}{l}\text { Type of surgery } \\
\text { for relapse }\end{array}$ & Status & $\begin{array}{c}\text { Follow-up } \\
\text { (months) }\end{array}$ \\
\hline Present study & 2018 & 47 & 47 & $\begin{array}{c}19 \mathrm{EE} \\
28 \text { combined }\end{array}$ & $100 \%$ CR & 2 & 2 OPF & $100 \%$ NED & 43 \\
\hline Albathi ${ }^{16}$ & 2018 & 4 & 4 & $\mathrm{EE}+\operatorname{Tr} \mathrm{P}$ & $100 \%$ CR & 0 & - & $100 \%$ NED & 24 \\
\hline Adriansen ${ }^{20}$ & 2015 & 20 & 20 & $\mathrm{EE}$ & $100 \%$ CR & 2 & $\mathrm{EE}$ & $100 \%$ NED & 42 \\
\hline Ungari ${ }^{27}$ & 2015 & 35 & $\begin{array}{l}5 \mathrm{FS} \\
13 \mathrm{FE}\end{array}$ & OPF & $100 \%$ CR & 2 & $2 \mathrm{OPF}$ & $100 \%$ NED & $>12$ \\
\hline Pagella ${ }^{28}$ & 2014 & 73 & $\begin{array}{l}2 \mathrm{FS} \\
8 \mathrm{FE}\end{array}$ & EE & $100 \%$ CR & 0 & - & $100 \%$ NED & 58 \\
\hline Sciarretta 29 & 2014 & 110 & $\begin{array}{l}7 \mathrm{FR} \\
4 \mathrm{FS}\end{array}$ & EE & $100 \%$ CR & $\begin{array}{l}1 \mathrm{FR} \\
1 \mathrm{FS}\end{array}$ & $\begin{array}{c}1 \mathrm{EE}(\mathrm{FR}) \\
1 \mathrm{OPF}(\mathrm{FS})\end{array}$ & $100 \%$ NED & 56.7 \\
\hline \multirow[t]{2}{*}{$\operatorname{Kim}^{30}$} & 2012 & 578 & 22 (origin) & $\begin{array}{c}10 \text { EE } \\
8 \text { combined } \\
4 \text { external }\end{array}$ & $100 \%$ CR & 6 & $\mathrm{~N} / \mathrm{A}$ & $\mathrm{N} / \mathrm{A}$ & 41 \\
\hline & & & 89 (extension) & $\begin{array}{c}59 \text { EE } \\
20 \text { combined } \\
10 \text { external }\end{array}$ & & 24 & & & \\
\hline Gotlib $^{21}$ & 2012 & 2 & 2 & $\mathrm{EE}$ & $100 \%$ CR & $\mathrm{N} / \mathrm{A}$ & $\mathrm{N} / \mathrm{A}$ & $\begin{array}{l}50 \% \text { NED } \\
50 \% \text { N/A }\end{array}$ & 12 \\
\hline Walgama ${ }^{24}$ & 2012 & 49 & 49 & $\begin{array}{c}31 \mathrm{EE} \\
13 \mathrm{OPF} \\
5 \mathrm{EFT}\end{array}$ & $100 \%$ CR & 11 & $\begin{array}{l}8 \mathrm{EE} \\
1 \mathrm{EFT} \\
2 \mathrm{OPF}\end{array}$ & $100 \%$ NED & 27 \\
\hline $\operatorname{Lian}^{31}$ & 2012 & 26 & 1 & $\mathrm{EE}$ & $100 \%$ CR & $\mathrm{N} / \mathrm{A}$ & $\mathrm{N} / \mathrm{A}$ & $100 \%$ NED & 28.2 \\
\hline Kamel $^{32}$ & 2012 & 119 & 6 & EE & $100 \%$ CR & 0 & - & $100 \%$ NED & 27 \\
\hline Bathma ${ }^{33}$ & 2011 & 13 & $4 \mathrm{FR}$ & $\mathrm{EE}$ & $100 \%$ CR & $2^{\S}$ & $\mathrm{EE}$ & $100 \%$ NED & 40 \\
\hline Lombardi ${ }^{34}$ & 2011 & 212 & 11 & $\mathrm{EE}$ & $100 \%$ CR & 2 & $\begin{array}{l}1 \mathrm{EE} \\
1 \mathrm{OPF}\end{array}$ & $100 \%$ NED & 53.8 \\
\hline Dragonetti ${ }^{35}$ & 2011 & 84 & $\begin{array}{l}3 \mathrm{FS} \\
5 \mathrm{FR}\end{array}$ & $\begin{array}{c}6 \mathrm{EE} \\
2 \mathrm{OPF}\end{array}$ & $100 \%$ CR & $1(\mathrm{FR})$ & OPF & $100 \%$ NED & 39.5 \\
\hline Gras-Cabrerizo ${ }^{36}$ & 2010 & 79 & 8 (extension) & $\begin{array}{c}5 \mathrm{EE} \\
3 \text { external }\end{array}$ & $100 \%$ CR & $\mathrm{N} / \mathrm{A}$ & $\mathrm{N} / \mathrm{A}$ & $\mathrm{N} / \mathrm{A}$ & $>12$ \\
\hline Sham $^{37}$ & 2009 & 56 & 3 & $\begin{array}{c}1 \mathrm{EE} \\
2 \mathrm{ExFS}^{+}\end{array}$ & $100 \%$ CR & 3 & $\begin{array}{l}2 \text { ExFS } \\
1 \text { ExFS + } \\
\text { Lothrop }\end{array}$ & $\begin{array}{l}89 \% \text { NED } \\
11 \% \text { DOC }\end{array}$ & 84 \\
\hline Yoon ${ }^{15}$ & 2009 & 18 & 18 & $\begin{array}{l}2 \mathrm{OPF} \\
5 \mathrm{EFT}\end{array}$ & $100 \% \mathrm{CR}$ & 4 & $\begin{array}{l}3 \mathrm{EE} \\
1 \mathrm{EFT}\end{array}$ & $100 \%$ NED & 36.6 \\
\hline Eweiss ${ }^{22}$ & 2009 & 4 & 4 & EE & $100 \%$ CR & 1 & OPF & $100 \%$ NED & $\mathrm{N} / \mathrm{A}$ \\
\hline Landsberg ${ }^{38}$ & 2008 & 30 & 2 & $\mathrm{EE}$ & $\begin{array}{l}50 \% \text { CR } \\
50 \% \text { PR }\end{array}$ & 1 & - & $\begin{array}{l}50 \% \text { NED } \\
50 \% \text { AWD }\end{array}$ & 40 \\
\hline Mackle ${ }^{39}$ & 2008 & 55 & 1 & OPF & $100 \%$ CR & $\mathrm{N} / \mathrm{A}$ & $\mathrm{N} / \mathrm{A}$ & $\mathrm{N} / \mathrm{A}$ & $>36$ \\
\hline Zhang ${ }^{23}$ & 2008 & 9 & $9^{*}$ & $\mathrm{EE}$ & $100 \%$ CR & 0 & $1 \overline{\mathrm{OPF}}$ & $100 \%$ NED & 15.1 \\
\hline Sautter ${ }^{19}$ & 2007 & 5 & 5 & $\begin{array}{l}4 \mathrm{EE} \\
1 \mathrm{EFT}\end{array}$ & $100 \%$ CR & 0 & - & $100 \%$ NED & 16.8 \\
\hline Mortuaire 40 & 2007 & 65 & 3 & $\mathrm{~N} / \mathrm{A}$ & $100 \%$ CR & 1 & External & $N / A$ & 28 \\
\hline Woodworth ${ }^{41}$ & 2007 & 110 & $\begin{array}{l}10 \mathrm{FR} \\
9 \mathrm{FS}\end{array}$ & $\begin{array}{l}10 \mathrm{EE} \\
5 \mathrm{OPF} \\
2 \mathrm{EFT} \\
2 \mathrm{EE}+ \\
\text { Lynch }\end{array}$ & $100 \%$ CR & 8 & $\begin{array}{c}5 \mathrm{EE} \\
1 \mathrm{EFT} \\
1 \mathrm{EE}+\mathrm{OPF} \\
1 \mathrm{EE}+\text { Lynch }\end{array}$ & $100 \%$ NED & 40 \\
\hline Minovi ${ }^{42}$ & 2006 & 87 & 13 & $\begin{array}{l}4 \mathrm{EE} \\
9 \mathrm{OPF}\end{array}$ & $100 \%$ CR & $\mathrm{N} / \mathrm{A}$ & $\mathrm{N} / \mathrm{A}$ & $100 \%$ NED & 74 \\
\hline
\end{tabular}


Table V. Review of English literature on surgical treatment of frontal sinus inverted papilloma (2002-2017).

\begin{tabular}{|c|c|c|c|c|c|c|c|c|c|}
\hline Author & Year & $\begin{array}{l}\text { Total } \\
\text { cases }\end{array}$ & $\begin{array}{l}\text { Cases with FS } \\
\text { involvement }\end{array}$ & $\begin{array}{c}\text { Type } \\
\text { of surgery }\end{array}$ & Results & $\begin{array}{c}\text { No. } \\
\text { of relapses }\end{array}$ & $\begin{array}{l}\text { Type of surgery } \\
\text { for relapse }\end{array}$ & Status & $\begin{array}{l}\text { Follow-up } \\
\text { (months) }\end{array}$ \\
\hline Katori ${ }^{43}$ & 2005 & 39 & $\begin{array}{c}2 \text { (origin) } \\
8 \text { (extension) }\end{array}$ & EE, external & $100 \%$ CR & $5^{\#}$ & EE, external & $\mathrm{N} / \mathrm{A}$ & 35 \\
\hline Dubin ${ }^{14}$ & 2005 & 18 & 6 & $\begin{array}{c}2 \mathrm{EE} \\
1 \mathrm{OPF} \\
3 \mathrm{EE}+\mathrm{OPF}\end{array}$ & $\begin{array}{l}67 \% \text { CR } \\
33 \% \text { PR }\end{array}$ & $3^{\circ}$ & $\begin{array}{l}2 \mathrm{EE} \\
1 \mathrm{OPF}\end{array}$ & $\begin{array}{l}83 \% \text { NED } \\
17 \% \text { DOC }\end{array}$ & 13.3 \\
\hline Jameson ${ }^{44}$ & 2005 & 18 & $\begin{array}{l}1 \mathrm{FS} \\
1 \mathrm{FR}\end{array}$ & $\begin{array}{l}1 \mathrm{OPF} \\
1 \mathrm{EE}\end{array}$ & $100 \% \mathrm{CR}$ & 0 & - & $100 \%$ NED & 29 \\
\hline Wolfe 45 & 2004 & 50 & $\begin{array}{l}3 \mathrm{FS} \\
2 \mathrm{FR}\end{array}$ & $\begin{array}{c}3 \text { EE } \\
1 \text { OPF } \\
1 \text { Lynch }\end{array}$ & $100 \%$ CR & 0 & - & $100 \%$ NED & 31.1 \\
\hline
\end{tabular}

FS: Frontal Sinus; FR: Frontal Recess; FE: Fronto-ethmoidal; EE: Endoscopic Endonasal; OPF: Osteoplastic Flap; EFT: Endoscopic Frontal Trephination; ExFs: External Frontal Sinusotomy: Lynch: external approach through Lynch incision; TrP: transpalpebral; CR: Complete Resection; PR: Partial Resection; NED: No Evidence of Disease; AWD: Alive With Disease; DOC: Dead of Other Causes; ; : the 2 relapses occurred in the same patient; ; : the external frontal sinusotomy was realised via an eyebrow incision; ": frontal sinus and frontal recess are considered altogether; \#: 1 relapse in frontal sinus originally involved only the ethmoid, 2 patients recurred twice each after endoscopic and external approach (not furtherly specified); : 2 out of 3 cases were in fact persistence: a staged OPF was performed because of suspicious partial resection after endoscopic approach, confirmed by pathology.

EEA should be used whenever feasible and able to obtain radical resection of inverted papilloma in the frontal sinus. On the other hand, a combined approach with an OPF has to be used whenever dictated by the localisation of the tumour, and particularly by its sites of attachment inside the frontal sinus, even when the point of origin is situated outside of the sinus (i.e. in the ethmoidal compartment). To note, a new approach to the far lateral frontal sinus, the so-called endoscopic orbital transposition ${ }^{10}$, has lately changed our paradigm toward a totally endoscopic endonasal tumour removal in selected cases.

In conclusion, the present study emphasises that what really matters is complete tumour eradication, possibly using the least invasive approach for the patient. Endoscopic endonasal techniques have drammatically changed the approach to inverted papilloma, although the endoscope remains a very useful tool even if not the solution for every case.

\section{Conflict of interest statement}

None declared.

\section{References}

1 Lund VJ, Stammberger H, Nicolai P, et al. European position paper on endoscopic management of tumours of the nose, paranasal sinuses and skull base. Rhinol Suppl 2010;22:1-143.

2 Lund VJ. Optimum management of inverted papilloma. J Laryngol Otol 2000;114:194-7.

3 Mirza S, Bradley PJ, Acharya A, et al. Sinonasal inverted papillomas: recurrence, and synchronous and metachronous malignancy. $\mathrm{J}$ Laryngol Otol 2007;121:857-64.

4 Karligkiotis A, Lepera D, Volpi L, et al. Survival outcomes after endoscopic resection for sinonasal squamous cell carcinoma arising on inverted papilloma. Head Neck 2016;38:1604-14.
5 Lawson W, Patel ZM. The evolution of management for inverted papilloma: an analysis of 200 cases. Otolaryngol Head Neck Surg 2009;140:330-5.

6 Karligkiotis A, Bignami M, Terranova P, et al. Oncocytic Schneiderian papillomas: Clinical behavior and outcomes of the endoscopic endonasal approach in 33 cases. Head Neck 2014;36:624-30.

7 Busquets JM, Hwang PH. Endoscopic resection of sinonasal inverted papilloma: a meta-analysis. Otolaryngol Head Neck Surg 2006;134:476-82.

8 Tomenzoli D, Castelnuovo P, Pagella F, et al. Different endoscopic surgical strategies in the management of inverted papilloma of the sinonasal tract: experience with 47 patients. Laryngoscope 2004;114:193-200.

9 Draf W. Endonasal micro-endoscopic frontal sinus surgery: The fulda concept. Oper Tech Otolayngol Head Neck Surg 1991;2:234-40.

10 Karligkiotis A, Pistochini A, Turri-Zanoni M, et al. Endoscopic endonasal orbital transposition to expand the frontal sinus approaches. Am J Rhinol Allergy 2015;29:449-56.

11 Mohan S, Nair S, Sharma M, et al. Inverted papilloma of frontal sinus with intracranial extension. Med J Armed Forces India 2015;71(Suppl 1):S152-5.

12 Vural E, Suen JY, Hanna E. Intracranial extension of inverted papilloma: An unusual and potentially fatal complication. Head Neck 1999;21:703-6.

13 Krouse JH. Development of a staging system for inverted papilloma. Laryngoscope 2000;110:965-8.

14 Dubin MG, Sonnenburg RE, Melroy CT, et al. Staged endoscopic and combined open/endoscopic approach in the management of inverted papilloma of the frontal sinus. Am J Rhinol 2005;19:442-5.

15 Yoon BN, Batra PS, Citardi MJ, et al. Frontal sinus inverted papilloma: surgical strategy based on the site of attachment. Am J Rhinol Allergy 2009;23:337-41.

16 Albathi M, Ramanathan M, Lane AP, et al. Combined endonasal and eyelid approach for management of extensive frontal sinus inverting papilloma. Laryngoscope 2018;128:3-9.

17 Volpi L, Pistochini A, Bignami M, et al. A novel technique for tailoring frontal osteoplastic flaps using the ENT magnetic navigation system. Acta Otolaryngol 2012;132:645-50. 
18 Hardy JM, Montgomery WW. Osteoplastic frontal sinusotomy: an analysis of 250 operations. Ann Otol Rhinol Laryngol 1976;85(4 Pt 1):523-32.

19 Sautter NB, Citardi MJ, Batra PS. Minimally invasive resection of frontal recess/sinus inverted papilloma. Am J Otolaryngol 2007;28:221-4

20 Adriaensen GF, van der Hout MW, Reinartz SM, et al. Endoscopic treatment of inverted papilloma attached in the frontal sinus/recess. Rhinology 2015;53:317-24.

${ }^{21}$ Gotlib T, Krzeski A, Held-Ziółkowska M, et al. Endoscopic transnasal management of inverted papilloma involving frontal sinuses. Wideochir Inne Tech Maloinwazyjne 2012;7:299-303.

22 Eweiss A, Al Ansari A, Hassab M. Inverted papilloma involving the frontal sinus: a management plan. Eur Arch Otorhinolaryngol 2009;266:1895-901.

23 Zhang L, Han D, Wang C, et al. Endoscopic management of the inverted papilloma with attachment to the frontal sinus drainage pathway. Acta Otolaryngol 2008;128:561-8.

24 Walgama E, Ahn C, Batra PS. Surgical management of frontal sinus inverted papilloma: a systematic review. Laryngoscope 2012;122:1205-9.

25 Mak W, Webb D, Al-Salihi S, et al. Sinonasal inverted papilloma recurrence rates and evaluation of current staging systems. Rhinology 2018;56:407-14.

26 Voultsos P, Casini M, Ricci G, et al. A proposal for limited criminal liability in high-accuracy endoscopic sinus surgery. Acta Otorhinolaryngol Ital 2017;37:65-71.

27 Ungari C, Riccardi E, Reale G, et al. Management and treatment of sinonasal inverted papilloma. Ann Stomatol (Roma) 2016;6:87-90.

28 Pagella F, Pusateri A, Giourgos G, et al. Evolution in the treatment of sinonasal inverted papilloma: pedicle-oriented endoscopic surgery. Am J Rhinol Allergy 2014;28:75-81.

29 Sciarretta V, Fernandez IJ, Farneti P, et al. Endoscopic and combined external-transnasal endoscopic approach for the treatment of inverted papilloma: analysis of 110 cases. Eur Arch Otorhinolaryngol 2014;271:1953-9.

30 Kim DY, Hong SL, Lee CH, et al. Inverted papilloma of the nasal cavity and paranasal sinuses: a Korean multicenter study. Laryngoscope 2012;122:487-94.

31 Lian F, Juan H. Different endoscopic strategies in the manage- ment of recurrent sinonasal inverted papilloma. J Craniofac Surg 2012;23:e44-8.

32 Kamel RH, Abdel Fattah AF, et al. Origin oriented management of inverted papilloma of the frontal sinus. Rhinology 2012;50:262-8.

33 Bathma S, Harvinder S, Philip R, et al. Endoscopic management of sinonasal inverted papilloma. Med J Malaysia 2011;66:15-8.

34 Lombardi D, Tomenzoli D, Buttà L, et al. Limitations and complications of endoscopic surgery for treatment for sinonasal inverted papilloma: a reassessment after 212 cases. Head Neck 2011;33:1154-61.

35 Dragonetti A, Gera R, Sciuto A, et al. Sinonasal inverted papilloma: 84 patients treated by endoscopy and proposal for a new classification. Rhinology 2011;49:207-13.

36 Gras-Cabrerizo JR, Massegur-Solench H, Pujol-Olmo A, et al. Endoscopic medial maxillectomy with preservation of inferior turbinate: how do we do it? Eur Arch Otorhinolaryngol 2011;268:389-92.

37 Sham CL, Woo JK, van Hasselt CA, et al. Treatment results of sinonasal inverted papilloma: an 18-year study. Am J Rhinol Allerg 2009;23:203-11.

38 Landsberg R, Cavel O, Segev Y, et al. Attachment-oriented endoscopic surgical strategy for sinonasal inverted papilloma. Am J Rhinol 2008;22:629-34

39 Mackle T, Chambon G, Garrel R, et al. Endoscopic treatment of sinonasal papilloma: a 12 year review. Acta Otolaryngol 2008;128:670-4.

40 Mortuaire G, Arzul E, Darras JA, et al. Surgical management of sinonasal inverted papillomas through endoscopic approach. Eur Arch Otorhinolaryngol 2007;264:1419-24.

${ }^{41}$ Woodworth BA, Bhargave GA, Palmer JN, et al. Clinical outcomes of endoscopic and endoscopic-assisted resection of inverted papillomas: a 15-year experience. Am J Rhinol 2007;21:591-600.

42 Minovi A, Kollert M, Draf W, et al. Inverted papilloma: feasibility of endonasal surgery and long-term results of 87 cases. Rhinology 2006;44:205-10.

43 Katori H, Tsukuda M. Staging of surgical approach of sinonasal inverted papilloma. Auris Nasus Larynx 2005;32:257-63.

44 Jameson MJ, Kountakis SE. Endoscopic management of extensive inverted papilloma. Am J Rhinol 2005;19:446-51.

45 Wolfe SG, Schlosser RJ, Bolger WE, et al. Endoscopic and endoscope-assisted resections of inverted sinonasal papillomas. Otolaryngol Head Neck Surg 2004;131:174-9.

Received: August 13, 2018 - Accepted: October 15, 2018

How to cite this article: Pietrobon G, Karligkiotis A, Turri-Zanoni M, et al. Surgical management of inverted papilloma involving the frontal sinus: a practical algorithm for treatment planning. Acta Otorhinolaryngol Ital 2019;39:28-39. https://doi.org/10.14639/0392-100X-2313

Address for correspondence: Giacomo Pietrobon, Division of Otorhinolaryngology, Department of Biotechnology and Life Sciences, University of Insubria, ASST Sette Laghi, Ospedale di Circolo e Fondazione Macchi, via Guicciardini 9, 21100 Varese, Italy. Tel. +39 0332 393278. Fax +39 0332 39327. E-mail: giacomo.pietrobon@gmail.com 